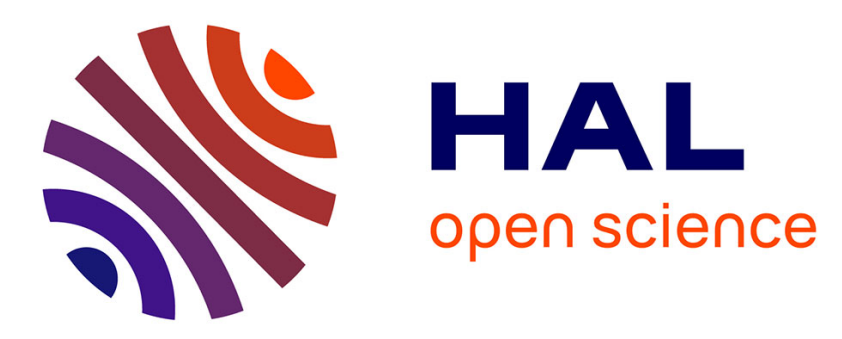

\title{
Sources partitioning in the diet of the shipworm Bankia carinata (J.E. Gray, 1827): An experimental study based on stable isotopes
}

François Charles, Pierre-Guy Sauriau, Fabien Aubert, Benoit Lebreton, François Lantoine, Pascal Riera

\section{To cite this version:}

François Charles, Pierre-Guy Sauriau, Fabien Aubert, Benoit Lebreton, François Lantoine, et al.. Sources partitioning in the diet of the shipworm Bankia carinata (J.E. Gray, 1827): An experimental study based on stable isotopes. Marine Environmental Research, 2018, 142, pp.208-213. 10.1016/j.marenvres.2018.10.009 . hal-01913763

\section{HAL Id: hal-01913763 https: / hal.sorbonne-universite.fr/hal-01913763}

Submitted on 6 Nov 2018

HAL is a multi-disciplinary open access archive for the deposit and dissemination of scientific research documents, whether they are published or not. The documents may come from teaching and research institutions in France or abroad, or from public or private research centers.
L'archive ouverte pluridisciplinaire HAL, est destinée au dépôt et à la diffusion de documents scientifiques de niveau recherche, publiés ou non, émanant des établissements d'enseignement et de recherche français ou étrangers, des laboratoires publics ou privés. 
Sources partitioning in the diet of the shipworm Bankia carinata (J.E. Gray, 1827): an experimental study based on stable isotopes

Authors information:

François Charles $^{1^{*}}$, Pierre-Guy Sauriau ${ }^{2}$, Fabien Aubert ${ }^{2}$, Benoît Lebreton ${ }^{2}$, François Lantoine ${ }^{1}$ and Pascal Riera ${ }^{3}$

Address:

${ }^{1}$ Sorbonne Université, UPMC Univ Paris 06, CNRS, Laboratoire d'Ecogéochimie des Environnements Benthiques (LECOB), Observatoire Océanologique de Banyuls, 66650 Banyuls-sur-Mer, France 2 Université de La Rochelle, CNRS, UMR 7266 - Littoral Environnement et Sociétés (LIENSs), 2 rue Olympe de Gouges, 17000 La Rochelle, France

${ }^{3}$ Sorbonne Université, CNRS - UMR7144 - Station Biologique de Roscoff, 29680 Roscoff, France

${ }^{*}$ Correspondence :

Email : francois.charles@obs-banyuls.fr;

Phone : +33(0)4 68887335

\section{Abstract}

Adaptations that allow teredinids to maintain and thrive on wood, a nutritionally unbalanced food, make these marine bivalves remarkable. Capable of filter-feeding, shipworms house endosymbiotic bacteria synthesizing cellulolytic enzymes for digestion of wood carbohydrates and providing nitrogen to their host through nitrogen fixation. To what extent each of these nutrition modes contributes to the shipworm's metabolism remains an open question. In this experimental study, we estimated source partitioning through the determination of $\delta^{13} \mathrm{C}$ and $\delta^{15} \mathrm{~N}$ values in original biological samples. For this purpose, pieces of common alder (Alnus glutinosa) were immersed at a coastal station of the northwestern Mediterranean Sea. The shipworm Bankia carinata infected wood logs and stable isotope mixing models suggested it got most of the carbon and nitrogen it needs from separate sources. From 71 to $77 \%$ of the carbon was derived from the digestion of wood carbohydrates, whereas between 42 and $82 \%$ of the nitrogen originated from $\mathrm{N}_{2}$ fixation. These first semi-quantitative estimations suggest that the contribution of $\mathrm{N}_{2}$ fixers to nitrogen requirements of this shipworm species is far from incidental.

Keywords: Teredinidae, Trophic ecology, Stable isotope, in situ experiment, Mediterranean Sea 


\section{Sources partitioning in the diet of Bankia carinata}

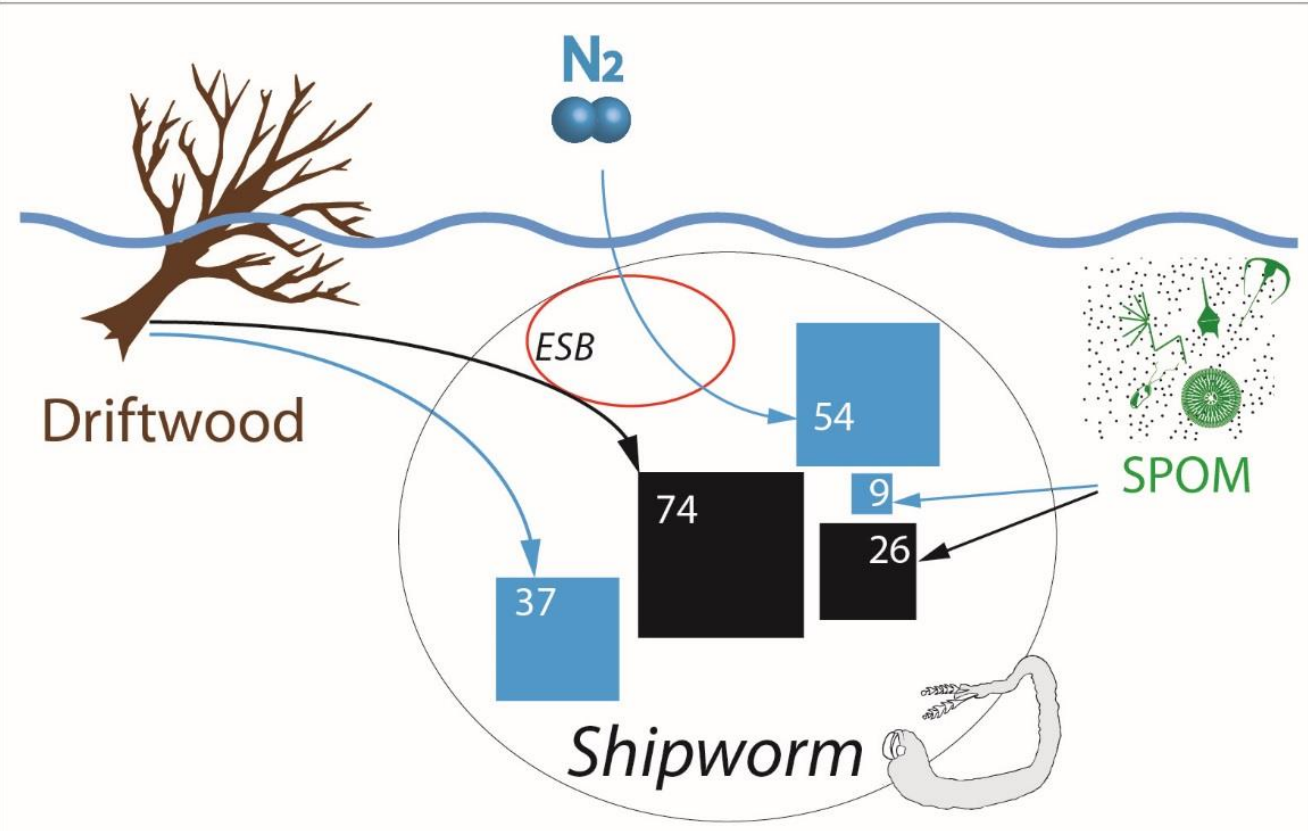

Highlights:

- Nearly all teredinid mollusks are obligate wood eaters.

- Food sources partitioning in the diet of Bankia carinata was investigated based on stable isotope analysis.

- The shipworms get the carbon and nitrogen they need from separate sources.

- $\quad \delta^{13} \mathrm{C}$ values strongly suggest that most carbon is derived from wood.

- Stable isotope mixing models indicate that $\mathrm{N}_{2}$ fixed by endosymbionts provides at least half of the nitrogen content of the bivalves. 


\section{Introduction}

Wood-boring teredinid bivalves occur on wood scattered at sea. In spite of being pests for all kinds of maritime wooden structures, these mollusks, commonly known as shipworms, are one of the finest examples of adaptation within the tree of life (Cragg et al., 2015). The strategy that enables these bivalves to digest wood and supplement a nutritionally imbalanced diet has been debated for over a century. While it was shown some time ago that shipworms were able to digest carbohydrates from wood (Dore and Miller, 1923; Miller and Boynton, 1926), the coverage of nitrogen requirements has remained under discussion (Carpenter and Culliney, 1975; Greenfield, 1952; Lasker and Lane, 1953; Nishimoto et al., 2009; Pechenik et al., 1979; Yamanaka et al., 2015) to explain how some species (Gallager et al., 1981) possess the ability to maintain and thrive in the absence of any other food source than wood.

Rather than taking advantage of an association with its gut microflora which otherwise is scarce (Betcher et al., 2012), shipworms produce endogenous lignocellulolytic enzymes (Sabbadin et al., 2018), but also rely on dense populations of intracellular bacterial symbionts hosted in the gland of Deshayes, a cluster of bacteriocytes located within the gills (Popham and Dickson, 1973). The many types of bacteria housed in these eukaryotic cells can both digest wood carbohydrates and fix nitrogen gas (Distel et al., 2002; Waterbury et al., 1983). It has been demonstrated that wood-degrading enzymes produced by the endosymbionts were selectively translocated from the gills to the gut of the host (O'Connor et al., 2014), and that dissolved nitrogen fixed by the intracellular bacterial symbionts within the bacteriocytes could further be used for host metabolism (Lechene et al., 2007). All this makes teredinids a unique model in animal endosymbiosis (Lechene et al., 2007) and may explain how shipworms are able to use wood as a primary food source.

Marine wood-boring bivalves are indeed remarkable consumers in that the number of potential feeding sources differs according to whether one considers their carbon or nitrogen requirement. With regard to carbon sources, teredinids can rely on wood but also, as filter-feeding bivalves, on suspended particulate organic matter from sea water. Regarding nitrogen sources, wood content is seemingly inadequate to meet shipworms' requirements (Lasker and Lane, 1953; Carpenter and Culliney, 1975), but nitrogen incorporation from this source cannot be excluded (Greenfield, 1952; Yamanaka et al., 2015). Suspended organic particles are also sources of nitrogen but may remain incidental (Gallager et al., 1981) because the ability to filter feed in most shipworm species is reduced by the shortening of gill lamellae (Turner, 1966, Distel et al., 2011). Nitrogen fixation by endosymbionts (Lechene et al., 2007) is one further source. Even though the routes of $\mathrm{C}$ and $\mathrm{N}$ are known and common among shipworm species, the relative contribution of these routes to the shipworms' metabolism remains controversial particularly with respect to nitrogen.

Stable isotope compositions of marine organic matter, terrestrial plants and $\mathrm{N}_{2}$ dissolved in seawater are different (Peterson and Fry, 1987), and can therefore help in deciphering the composition of the shipworm's diet. To our knowledge, the few studies published on this topic were not conclusive about source partitioning (Nishimoto et al., 2009; Paalvast and van der Velde, 2013; Yamanaka et al., 2015). In this context, the aim of the present study was thus to investigate carbon and nitrogen source 
partitioning by shipworms via an in situ experimental approach and through the use of stable isotopes $\left(\delta^{13} \mathrm{C}, \delta^{15} \mathrm{~N}\right)$.

\section{Material and methods}

\subsection{Experimental design}

The experiment was performed from June 6 to October 24, 2016 in the Bay of Banyuls-sur-Mer, in the north-western Mediterranean Sea, France. Twelve $15 \mathrm{~cm}$ long sections were sawn from, a branch of a common alder tree, Alnus glutinosa (L.) Gaertner, a widespread tree species along the banks of La Massane, a local river which drains a small forested basin on the foothills of the French Pyrenees mountains. The bark-intact small logs were air-dried indoors for a full year before being arranged into packs and deployed at a coastal station (26 m depth; 42 $29^{\prime} 302 \mathrm{~N} ; 03^{\circ} 08^{\prime} 700 \mathrm{E}$ ). Each pack consisted of four 2.5 to $5.5 \mathrm{~cm}$ cross-section wooden pieces tied together with a Colson ${ }^{\mathrm{TM}}$ collar. Two packs were installed in June and an additional one on August 20. Wood packs were attached at one end to an anchor and at the other end to a polyethylene buoy in such a way that the wood blocks remained suspended between 1 and $1.5 \mathrm{~m}$ above the seabed (Fig. S1).

\subsection{Sampling and preparation for stable isotope analyses}

Potential food sources, namely alder wood within the experimental wood packs and suspended particulate organic matter (SPOM) from the surrounding sea water, were sampled on several occasions during the experiment. Alder wood was sampled on June 6 , at the time of deployment of the first wood packs, and on October 24 after time intervals of nearly 2 and 4.5 months from submersion. SPOM was sampled when installing the experiment, at two intermediate dates, July $7^{\text {th }}$ and September $8^{\text {th }}$, and at the end of the experiment. Consumers, namely animals present either on (i.e. Mytilus galloprovincialis, Hiatella arctica, Musculus subpictus, Serpula vermicularis, Spirobranchus triqueter, Ascidia conchilega) or inside (Bankia carinata) the wood logs, were sampled once, on October 24.

Three water samples were collected for SPOM near the submerged wood with a Niskin bottle $(10 \mathrm{~L})$ and pre-filtered through a $200 \mu \mathrm{m}$ mesh to remove large zooplankton and detritus. SPOM was then recovered by filtration on pre-combusted Whatman GF/F filters, $25 \mathrm{~mm}$ in diameter, $0.7 \mu \mathrm{m}$ pore size. The filters were then placed in individual petri dishes and dried in an oven at $50^{\circ} \mathrm{C}$ overnight. Dry filters were kept away from light in a desiccator until analysis.

Invertebrate species present at the surface of the wood packs were collected manually. Wood logs were then cut with a chisel for the collection of wood samples and shipworms. All the animals present were kept alive for $24 \mathrm{~h}$ in filtered sea water to allow evacuation of the gut contents and, if necessary, were then dissected to separate flesh from the shells. Wood chips and animal tissues were rinsed with deionised water and stored in aluminium foil at $-20^{\circ} \mathrm{C}$ until analysis. Freeze-dried tissues and wood samples were ground into a fine powder using a ball mill (MM 400, Retsch) and a sander (R3000, Dremel), respectively. These samples were then weighed into tin capsules (ca. 0.3 to $0.4 \mathrm{mg}$ for all sample tissue and wood carbon analysis, and ca. 4 to $5 \mathrm{mg}$ for wood nitrogen analysis).

SPOM samples may contain carbonates that are more enriched in ${ }^{13} \mathrm{C}$ than plant and animal tissues (DeNiro and Epstein, 1978). Accordingly, $\delta^{13} \mathrm{C}$ and $\delta^{15} \mathrm{~N}$ were analysed separately. For 
measurements of $\delta^{13} \mathrm{C}$ values, one half of each filter was acidified for $4 \mathrm{~h}$ with $37 \% \mathrm{HCl}$ acid vapours under moderate vacuum in a glass desiccator to remove carbonates (Malet et al., 2007). For measurements of $\delta^{15} \mathrm{~N}$ values, the remaining half of each filter was analysed without any pre-treatment, as acidification may alter nitrogen isotope composition (Bunn et al., 1995; Kennedy et al., 2005). The two sets of sub-samples (i.e. acidified half-filters and non-acidified half-filters) were packed separately into individual tin capsules.

\subsection{Stable isotope ratio measurements}

Carbon and nitrogen isotope composition was determined using an elemental analyser (Flash EA 1112, Thermo Scientific, Milan, Italy) coupled to a continuous-flow isotope-ratio mass spectrometer (Delta V Advantage with a Conflo IV interface, Thermo Scientific, Bremen Germany). Analyses were conducted at the LIENSs stable isotope facility at the University of La Rochelle, France. Data are expressed in the $\delta$ notation (in \%) as deviations from international standards (Vienna Pee Dee Belemnite for $\delta^{13} \mathrm{C}$ and $\mathrm{N}_{2}$ in air for $\left.\delta^{15} \mathrm{~N}\right)$ following the formula: $\delta \mathrm{X}=[($ Rsample /Rreference $)-1] \times$ $10^{3}$, with $\mathrm{R}={ }^{13} \mathrm{C} /{ }^{12} \mathrm{C}$ for carbon and ${ }^{15} \mathrm{~N} /{ }^{14} \mathrm{~N}$ for nitrogen. Calibration was done using reference materials (USGS-24, IAEA-CH6, IAEA-600 for carbon; IAEA-N2, IAEA-NO-3, IAEA-600 for nitrogen). Analytical precision was $0.15 \%$ for both $\mathrm{C}$ and $\mathrm{N}$ isotope analyses based on the analyses of acetanilide (Thermo Scientific) and peptone (Sigma-Aldrich) used as internal laboratory standards.

\subsection{Data analysis and statistical treatment}

All statistics were performed using $\mathrm{R}$, released by the R Foundation for Statistical Computing (R Core Team, 2013). First, from the R commander package (Fox and Vialat, 2017), non-parametric Mann-Whitney $U$ tests were run for testing the hypothesis that the distribution of data was the same between groups. In this context, data accounted for either $\delta$ values or $\mathrm{C} / \mathrm{N}$ ratio; groups for exposure intervals to seawater (2 vs 4.5 months), food sources (wood vs SPOM), or feeding modes (suspensionfeeding vs xylotrophy).

The Bayesian mixing model SIAR (Stable Isotope Analysis in R; Parnell et al., 2010) was used to infer the feasible contributions of carbon and nitrogen sources to the diet of the shipworms. Models were run for 200,000 iterations and the first 50,000 iterations were discarded. For SIAR calculations, $A$. glutinosa wood and SPOM were considered as potential sources of carbon while A. glutinosa, SPOM and dissolved $\mathrm{N}_{2}$ were considered as potential sources of nitrogen. Isotope compositions of SPOM and wood used as end-members into mixing models were averages of values measured all along the study to account for potential temporal variations of their isotope compositions. Trophic fractionation factors used in mixing models were $0.30 \pm 0.21 \%$ for $\delta^{13} \mathrm{C}$ values and $2.5 \pm 0.25 \%$ for $\delta^{15} \mathrm{~N}$ values, corresponding to values for invertebrate species (whole body) as reviewed by Caut et al. (2009). Concerning the specific utilization of dissolved $\mathrm{N}_{2}$ by the bivalves, we thus used the $\delta^{15} \mathrm{~N}$ of $0.6 \%$ given by Sigman et al. (2009) for the marine dissolved $\mathrm{N}_{2}$ and a fractionation of $-1 \%$ as suggested by these authors for the fixed $\mathrm{N}$ input to the ocean from $\mathrm{N}_{2}$ fixation. No fractionation was expected between the endosymbionts and their host (Conway et al., 1989).

\section{Results}




\subsection{Stable isotope compositions}

$\delta^{15} \mathrm{~N}$ and $\delta^{13} \mathrm{C}$ values of alder wood remained in narrow ranges around mean values of $-2.2 \%$ and $-29.2 \%$ for $\mathrm{N}$ and $\mathrm{C}$ isotopes, respectively (Table 1, Figure 1). Ranges of SPOM isotope compositions were slightly wider around mean time-integrated values of $3.4 \%$ and $-23.8 \%$ for $\delta^{15} \mathrm{~N}$ and $\delta^{13} \mathrm{C}$ values, respectively. Alder wood was significantly more ${ }^{15} \mathrm{~N}$ depleted and ${ }^{13} \mathrm{C}$ depleted than SPOM and contained two orders less nitrogen relative to its carbon content compared to SPOM (one-sided Mann-Whitney U-test, $p=1$ in all cases).

The number of animals present either on or inside the wood logs increased with exposure time intervals. Only one species of shipworm (Table 2), namely, Bankia carinata (J.E. Gray 1827), was observed. Most other taxonomic groups consisted of suspension-feeding species. As no significant difference for both $\delta^{15} \mathrm{~N}$ and $\delta^{13} \mathrm{C}$ values was observed between the two exposure intervals to seawater (two-sided Mann-Whitney $U$ test, $p=0.09, p=0.10$ ), $B$. carinata was considered a homogenous group. The average $\delta^{15} \mathrm{~N}$ value of the shipworm bodies was close to $0 \%$ and their content was highly depleted in ${ }^{13} \mathrm{C}$ with a mean $\delta^{13} \mathrm{C}$ value of $-27.5 \%$. Shipworms were much more ${ }^{15} \mathrm{~N}$ and ${ }^{13} \mathrm{C}$ depleted than known strict seston feeders such as $M$. galloprovincialis, $H$. arctica, M. subpictus, S. vermicularis, S. triqueter or $A$. conchilega (one-sided Mann-Whitney U-tests, $p=1$ for all cases). Higher $\mathrm{C} / \mathrm{N}$ ratios were observed in shipworms (one-sided Mann-Whitney U-tests, $p=1$ ) due to higher carbon (39.9 $\pm 1.9 \%$ versus 34.9 $\pm 3.3 \%)$ and lower nitrogen contents $(5.2 \pm 1.6 \%$ versus $8.4 \pm 1.6 \%)$ than in other consumers. The addition of trophic fractionation factors to alder wood isotope compositions demonstrates a slight shift between expected and measured of $\delta^{13} \mathrm{C}$ values in shipworms (Figure 1).

\subsection{Stable isotope mixing models}

Based on 95\% Bayesian credible intervals, wood and SPOM proportions to shipworms carbon diet ranged from 71 to $77 \%$ (mode $=74 \%$ ), and 23 to $29 \%$ (mode $=26 \%$ ), respectively (Figure $2 \mathrm{~A}$ ). As a result, alder wood contributed to most of the carbon assimilated by the shipworms during the experiment as compared to local SPOM. Among the three nitrogen sources (Figure 2B), the Bayesian mixing model suggested a major contribution from $\mathrm{N}_{2}$ fixation (ranging from 42 to $82 \%$, mode $=54 \%$ ) and from A. glutinosa (from $9 \%$ to $51 \%$, mode $=37 \%$ ), much higher than contribution of SPOM (7 to $13 \%$, mode $=9 \%$ )

\section{Discussion}

Bankia carinata resorted to all the pathways of carbon and nitrogen acquisition described in shipworms. The approach permitted us to determine estimates of nitrogen source contribution, even though the number of sources was too large to get a unique solution from standard linear mixing models. As expected, the conversion of isotope compositions into contributions to the shipworm diet confirmed that wood was the main source of carbon, but it primarily revealed the significant contribution of nitrogen fixation pathways to the nitrogen content.

\subsection{Source partitioning in the diet of B. carinata}


Bankia carinata possesses a large caecum storing wood particles and all features associated with xylotrophy in shipworms, including the presence of dense populations of endosymbiotic bacteria within the large interlamellar space of the single demibranch gills (Distel et al., 2011). In European waters, this shipworm has only been reported in the Mediterranean Sea (Turner, 1966) probably because of a preference for hypersaline conditions (Borges et al., 2014). Bankia carinata is a broadcast spawning species that releases fertilized eggs into the water for long periods of development, increasing larval dispersion. Growth in the genus Bankia is generally fast and produces adults of large size (Haderlie and Mellor, 1973; Maclntosh et al., 2014). This species is reported in the studied area together with Lyrodus pedicellatus, Teredo navalis and Nototeredo norvagica (Charles et al., 2018). As population dynamics patterns depend on reproductive modes, differences must be expected in food source partitioning between shipworm species according to the level of exhaustion of the wood resource.

The measurement of isotope ratios on the whole body of the borers corresponded to the isotopic signature of the flesh of the shipworms including those of the bacteria from the digestive tract and the endosymbionts from the gills. The digestive tract, however, contains relatively few bacteria (Betcher et al, 2012) and endosymbiont bacteria represent a negligible amount of matter compared to the tissues of the shipworm. Thence, it is reasonable to assume that the measurements made on the shipworms were essentially the values of the isotopic ratios in the tissues of the host.

The differences of $\delta^{13} \mathrm{C}$ and $\delta^{15} \mathrm{~N}$ values between $B$. carinata and SPOM highlighted that, despite being able to capture organic particles from water, $B$. carinata food resources drastically differ from those of strict filter feeders living in the same trophic conditions (Figure 1). Accordingly, from these results, most of the carbon in shipworms is clearly derived from the consumption of alder wood (Figure 2a). The carbon isotope mixing model suggested that SPOM could seemingly represent $25 \%$ of shipworm's diet. Structural tissues of wood mainly consist of carbohydrates and lignin but shipworms only digest carbohydrates (Dore and Miller, 1923; Miller and Boynton, 1926; Sabbadin et al., 2018). Carbohydrates are more enriched in ${ }^{13} \mathrm{C}$ than lignin (Benner et al., 1987), and this gives whole wood a $\delta^{13} \mathrm{C}$ value which probably led to underestimate the contribution of wood source. This was further suggested by the outputs of the mixing models based on $\delta^{15} \mathrm{~N}$ values. High carbon content in the shipworms reflects the accumulation of large amounts of glycogen (Greenfield, 1952; Potts, 1923) which serves as an energy store in bivalves (De Zwaan and Zandee, 1972) and has been shown to be exclusively derived from digestion of wood carbohydrates in the shipworm Lyrodus pedicellatus (Lane et al., 1952).

According to the SIAR mixing model, SPOM contributed about $10 \%$ in average of the nitrogen of the shipworms. Out of the two other potential sources, the mixing model suggested that nitrogen coming from endosymbiosis contributed to the nitrogen pool of the shipworm tissues at an equal or even greater level than alder wood. From the $\mathrm{C} / \mathrm{N}$ ratio, it appears that $B$. carinata had reduced nitrogen requirements relative to other bivalves but a nitrogen content 20 times higher than that of alder wood. Shipworms can rely on wood to acquire their nitrogen (Lasker and Lane, 1953; Yamanaka et al., 2015) but also through the association with the $\mathrm{N}_{2}$-fixing endosymbionts hosted in their gills (Lechene et al., 2007). Even though, by minimizing excretory losses, shipworms are extremely conservative with respect to nitrogen (Gallager et al., 1981), wood source alone can barely cover all their nitrogen needs. Together 
with recycling mechanisms, a polytrophic capacity is probably the best feeding strategy for balancing requirements in poor-nitrogen environments (Muscatine and Porter, 1977). Intracellular bacteria populations from the gland of Deshayes produce cellulolytic enzymes which presumably in combination with enzymes produced endogenously (Sabbadin et al., 2018) allow shipworms to digest efficiently large amounts of wood carbohydrates. Endosymbiotic bacteria probably fulfill their $\mathrm{N}_{2}$ fixing function with an equal efficiency to the benefit of their host. Accordingly, the conversion of dissolved nitrogen gas into shipworm biomass is likely far from being incidental as suggested by the present study.

\subsection{Carbon and nitrogen sources: scope of the study}

The $\delta^{15} \mathrm{~N}$ value of marine dissolved $\mathrm{N}_{2}$ was not measured but dissolved $\mathrm{N}_{2}$ in equilibrium with atmospheric $\mathrm{N}_{2}$ in the surface ocean has a $\delta^{15} \mathrm{~N}$ value that does not vary greatly from $0.6 \%$ (Sigman et al., 2009). Molecular nitrogen fixation commonly results in weak, slightly negative isotope fractionation (Wada and Hattori, 1979) and no fractionation between endosymbionts and their host was expected (Conway et al., 1989). As a result, the $\delta^{15} \mathrm{~N}$ value of dissolved gas nitrogen and fractionation factor implemented into the mixing model must be relatively close to the actual values. The slight ${ }^{15} \mathrm{~N}$ enrichment of shipworm tissue relative to dinitrogen suggests that $\mathrm{N}_{2}$ fixation through endosymbiotic interaction contributed significantly to the nitrogen content of the shipworm. The contribution of other pathways of dinitrogen-fixing (i.g., ingestion of planktonic diazotrophs or wood particles from nitrogenfixing tree species) would imply trophic enrichment factors and that would have led to the higher ${ }^{15} \mathrm{~N}$ enrichment of the shipworm.

Regarding wood source, Alnus glutinosa is a common tree species on the banks of European rivers. Alder wood, therefore, has good chance to end up at sea after events of river flooding. During this study, the characteristics of wood which was initially introduced dry into the water changed very little. $\delta^{13} \mathrm{C}$ values and $\mathrm{C} / \mathrm{N}$ ratios were representative of most terrestrial $\mathrm{C}_{3}$ primary producers and in the range of those found in the literature for tree wood (Nishimoto et al 2009; Paalvast and van der Velde 2013, Yamaka et al., 2015). $\delta^{15} \mathrm{~N}$ values of wood are more variable, showing particularly negative values as previously reported at this site by Carlier et al. (2007) or for terrestrial plants (Fogel et al., 2008; Zapata-Hernandez et al., 2016), including alder tree species (Chambers et al., 2004). Nitrogen incorporation pathways differ among tree species. Alder, which grows on poor quality soils is, for instance, able to supplement its needs through an association with nitrogen-fixing bacteria hosted in its roots (Hooker and Wheeler, 1987). Alnus incana is known to derive almost all its nitrogen from the atmosphere (Chambers et al., 2004). This assigned to the wood source a trophic position which probably led us to overestimate its contribution to the nitrogen content of the shipworm, at the expense of the other sources. It, therefore, should be kept in mind that the scope of this study concerns a nitrogenfixing tree species.

$\delta^{13} \mathrm{C}$ and $\delta^{15} \mathrm{~N}$ values of SPOM were consistent with previous measurements at the studied site (Carlier et al., 2007; Nahon et al., 2012) with ranges of temporal changes of nearly $2 \%$ for both elements. Marine SPOM is a mixture of living and dead particles (Fry, 1988) of which the total amount and the individual contribution changed according to the seasons and weather conditions. For instance, particles collected in July, when the weather was calm, had $\delta$ values and $\mathrm{C} / \mathrm{N}$ ratio representative of what is 
reported for plankton (Peterson et al., 1986), while low $\delta^{13} \mathrm{C}$ values and high $\mathrm{C} / \mathrm{N}$ ratio measured in June and October were characteristic at the studied site of surficial sediment resuspended after windy weather conditions (Charles et al., 2012). On these occasions, debris of vascular plants could be observed in the water samples and most photosynthetic pigments were degraded (data not shown). The sampling approach allowed thus to produce average values of $\delta$ and $C / N$ that best reflected the food source for the shipworms and the co-occurring common filter-feeding species over the study period. It, however, should be noted that sampled SPOM particles ranged from 0.7 to $200 \mu \mathrm{m}$, and there is considerable heterogeneity in natural abundances of ${ }^{13} \mathrm{C}$ and ${ }^{15} \mathrm{~N}$ among the discrete size classes of SPOM (Rau et al., 1990). $\delta^{13} \mathrm{C}$ and $\delta^{15} \mathrm{~N}$ values of the smallest size fractions of SPOM can be as low as $-25.3 \%$ and $-0.5 \%$, respectively (Rau et al., 1990). At the study site, the contribution of picophytoplankton is maximal at periods of low total chlorophyll a biomass, that is to say in summer and fall, with contribution reaching more than $60 \%$ in September (Charles et al 2005). This, according to the findings of Rau et al. (1990), may to some extents explain the depletion in heavy isotopes measured in the SPOM fraction during the sampling, and so the gap between the bulk SPOM value and strict-filter feeding consumers which retain, sort and select particles differentially according to their size and nutritional quality (Dubois and Colombo, 2014, Cresson et al., 2016). As a consequence, even though this cannot dramatically change the general scheme of food source contributions, the comparison of particle sorting efficiency needs to be investigated to further understand interspecific variations in trophic niches among shipworm species (Cresson et al., 2016, Paalvast and van der Velde, 2013).

\section{Conclusion}

This study, involving alder wood, provides a first quantitative estimate of the contribution of food sources to the diet of $B$. carinata. Most of the assimilated carbon originated from the wood and $\mathrm{N}_{2}$ fixers contributed significantly to nitrogen requirements of the shipworm. However, it must be stressed that in a previous study conducted on Teredo navalis (Paalvast and van der Velde 2013), the overwhelming amount of carbon and nitrogen was derived from SPOM rather than from the wood source. Availability of food sources may change over time and space between studies, but stable isotope composition of wood also varies according to tree species and each species of teredinids has its own traits of life. As a consequence, the relative importance of the symbiotic association could then be better appreciated by testing, on the one hand, several tree and shipworm species, and, on the other hand, by performing ${ }^{13} \mathrm{C}$ and ${ }^{15} \mathrm{~N}$ labelling experiments to quantitatively estimate the $\mathrm{C}$ and $\mathrm{N}$ pathways within the different potential components of the shipworms diet.

\section{Acknowledgments}

We thank Gaël Guillou for stable isotope analysis. We are grateful to Joseph Garrigue, curator of the Réserve Naturelle Nationale de la Forêt de la Massane for providing alder wood for the field experiment. We expressly thank Jean-Claude Roca and Bruno Hesse for the installation and recovery of wooden blocks at sea. We acknowledge Jan Ellis and Christian Nozais for the 'spell checking' and 'grammar checking' of the manuscript. This work was supported by the EC2CO (Écosphère Continentale et Côtière) national program of the CNRS-INSU, as part of the DRIL (Dynamique et Réactivité des 
Interfaces Littorales) topics, under the title: "De la forêt à la mer : Transfert et recyclage du bois mort sur la marge continentale méditerranéenne".

\section{References}

1. Benner, R., Hodson, R.E., 1987. Depletion of ${ }^{13} \mathrm{C}$ in lignin and its implications for stable carbon isotope studies, Nature 329, 708-710. https://doi.org/10.1038/329708a0 2. Betcer, D.L., Haygood, M.G., 2012. Microbial distribution and abundance in the digestive system of five https://doi.org/10.1371/journal.pone.0045309

3. Borges, L. M., Merckelbach, L. M., Sampaio, Í., Cragg, S. M., 2014. Diversity, environmental requirements, and biogeography of bivalve wood-borers (Teredinidae) in European coastal waters. Frontiers in Zoology 11, 13. https://doi.org/10.1186/1742-9994-11-13

4. Bunn, S. E., Loneragan, N. R., Kempster, M. A., 1995. Effects of acid washing on stable isotope ratios of $\mathrm{C}$ and $\mathrm{N}$ in penaeid shrimp and seagrass: implications for food-web studies using multiple stable isotopes. Limnology and Oceanography, 40, 622-625. https://doi.org/10.4319/lo.1995.40.3.0622

5. Carlier, A., Riera, P., Amouroux, J.-M., Bodiou, J.-Y., Grémare, A., 2007. Benthic trophic network in the Bay of Banyuls-sur-Mer (northwest Mediterranean, France): An assessment based on stable carbon and nitrogen isotopes analysis. Estuarine, Coastal and Shelf Science 72, 1-15. https://doi.org/10.1016/i.ecss.2006.10.001

6. Carpenter, E. J., Culliney, J. L. 1975. Nitrogen fixation in marine shipworms. Science, 187(4176), 551-552. https://doi.org/10.1126/science.187.4176.551

7. Chambers, C., Marshall, J.D., Danehy, R.J., 2004. Nitrogen uptake and turnover in riparian woody vegetation. Oecologia 140, 125-134. https://doi.org/10.1007/s00442-004-1565-8

8. Charles, F., Nozais, C., Pruski, A.M., Bourgeois, S., Méjanelle, L., Vétion, G., Rivière, G., Coston-Guarini, J., 2012. Ecodynamics of PAHs at a peri-urban site of the French Mediterranean Sea. Environmental Pollution 171, 256 - 254. https://doi.org/10.1016/j.envpol.2012.07.034.

9. Charles, F., Coston, J., Guarini, J.M., Lantoine, F., 2018. It's what's inside that counts: computer aided tomography for evaluating the rate and extent of wood consumption by shipworms. Journal of Wood Science. https://doi.org/10.1007/s10086-018-1716-x

10. Conway, N., Capuzzo, J.M., Fry, B., 1989. The role of endosymbiotic bacteria in the nutrition of Solemya velum: Evidence from a stable isotope analysis of endosymbionts and host. Limnology and Oceanography 34, 249-255. https://doi.org/10.4319/lo.1989.34.1.0249

11. Cragg, S.M., Beckham, G.T., Bruce, N.C., Bugg, T.D., Distel, D.L., Dupree, P., Etxabe, A.G., Goodell, B.S., Jellison, J., McGeehan, J.E., McQueen-Mason, S.J., Schnorr, K., Walton, P.H., Watts, J.E., Zimmer, M., 2015. Lignocellulose degradation mechanisms across the Tree of Life. Current Opinion in Chemical Biology 29, 108-119. https://doi.org/10.1016/j.cbpa.2015.10.018

12. Cresson, P., Ruitton, S., Harmelin-Vivien, M., 2016. Feeding strategies of co-occurring suspension feeders in an oligotrophic environment. Food Webs 6, 19-28. doi:10.1016/j.fooweb.2015.12.002

13. DeNiro, M. J., Epstein, S., 1978. Influence of diet on the distribution of carbon isotopes in animals. Geochimica et Cosmochimica Acta, 42, 495-506. https://doi.org/10.1016/00167037(78)90199-0

14. De Zwaan, A., Zandee, D.I., 1972. The utilization of glycogen and accumulation of some intermediates during anaerobiosis in Mytilus edulis L. Comparative Biochemistry and Physiology Part B: Comparative Biochemistry 43, 47-54. https://doi.org/10.1016/0305-0491(72)90200-3

15. Distel, D.L., Morrill, W., MacLaren-Toussaint, N., Franks, D., Waterbury, J., 2002. Teredinibacter turnerae gen. nov., sp. nov., a dinitrogen-fixing, cellulolytic, endosymbiotic gamma-proteobacterium isolated from the gills of wood-boring molluscs (Bivalvia: Teredinidae). International Journal of Systematic and Evolutionary Microbiology 52, 2261-2269. https://doi.org/10.1099/ijs.0.02184-0 16. Distel, D. L., Amin, M., Burgoyne, A., Linton, E., Mamangkey, G., Morrill, W., ... Yang, J. 2011. Molecular phylogeny of Pholadoidea Lamarck, 1809 supports a single origin for xylotrophy (wood feeding) and xylotrophic bacterial endosymbiosis in Bivalvia. Molecular Phylogenetics and Evolution, 61(2), 245-254. https://doi.org/10.1016/j.ympev.2011.05.019 
17. Dore, W.H., Miller R.C., 1923. The digestion of wood by Teredo navalis. University of California publications in zoology 22, 383-399.

18. Dubois, S.F., Colombo, F., 2014. How picky can you be? Temporal variations in trophic niches of co-occurring suspension-feeding species. Food Webs 1, 1-9.

https://doi.org/10.1016/j.fooweb.2014.07.001

19. Fogel, M.L., Wooller, M.J., Cheeseman, J., Smallwood, B.J., Roberts, Q., Romero, I., Meyers, M.J., 2008. Unusually negative nitrogen isotopic compositions $\left(\delta^{15} \mathrm{~N}\right)$ of mangroves and lichens in an oligotrophic, microbially-influenced ecosystem. Biogeosciences 5, 1693-1704. https://doi.org/10.5194/bg-5-1693-2008

20. Fox, J., Bouchet-Valat, M. 2017. Rcmdr: R Commander. R package version 2.3-2.

21. Fry, B., 1988. Food web structure on Georges Bank from stable C, N, and S isotopic compositions. Limnology and Oceanography 33, 1182-1190. https://doi.org/10.4319/lo.1988.33.5.1182

22. Gallager, S.M., Turner, R.D., Berg Jr., C.J., 1981. Physiological aspects of wood consumption, growth, and reproduction in the shipworm Lyrodus pedicellatus Quatrefages (Bivalvia: Teredinidae). Journal of experimental marine Biology and Ecology 52, 63-77. https://doi.org/10.1016/00220981(81)90171-4

23. Greenfield, L.J., 1952. Observation on the nitrogen and glycogen content of Teredo (Lyrodus) pedicellate de Quatrefages at Miami, Florida. Bulletin of Marine Science of the Gulf and Caribbean 2, 486-496.

24. Haderlie E.C., Mellor, J.C., 1973. Settlement, growth rates and depth preference of the shipworm Bankia setacea (Tryon) in Monterey Bay. The Veliger 15, 265-286.

25. Hooker, J. E., Wheeler, C.T., 1987. The effectivity of Frankia for nodulation and nitrogen fixation in Alnus rubra and A. glutinosa. Physiologia Plantarum 70, 333-41. https://doi.org/10.1111/j.13993054.1987.tb06152.x.

26. Kennedy, P., Kennedy, H., Papadimitriou, S., 2005. The effect of acidification on the determination of organic carbon, total nitrogen and their stable isotopic composition in algae and marine sediment. Rapid Communications in Mass Spectrometry 19, 1063-1068

27. Lane, C.E., Posner, G.S., Greenfield L.J., 1952. The distribution of glycogen content in the Shipworm Teredo (Lyrodus) pedicellata de Quatrefages at Miami, Florida. Bulletin of Marine Science of the Gulf and Caribbean 2, 385-392

28. Lasker, R., Lane, C.E., 1953. The origin and distribution of nitrogen in Teredo bartschi Clapp. The Biological Bulletin 105, 316-319. https://doi.org/10.2307/1538647.

29. Lechene C.P., Luyten, Y., McMahon, G., Distel, D.L., 2007. Quantitative imaging of nitrogen fixation by individual bacteria within animal cells. Science, New Series 317, 1563-1566. https://doi.org/ 10.1126/science.1145557

30. Maclntosh, H., de Nys, R., Whalan, S., 2014. Contrasting life histories in shipworms: Growth, reproductive development and fecundity. Journal of Experimental Marine Biology and Ecology, 459, 80-86. https://doi.org/10.1016/j.jembe.2014.05.015

31. Malet, N., Sauriau, P.-G., Ryckaert, M., Malestroit, P., Guillou, G., 2008. Dynamics and sources of suspended particulate organic matter in the Marennes-Oléron oyster farming bay: insights from stable isotopes and microalgae ecology. Estuarine and Coastal Marine Science, 78, 576-586. https://doi.org/10.1016/i.ecss.2007.11.001

32. Miller, R.C., Boynton, L.C., 1926. Digestion of wood by shipworms. Science 63,1638, 524-524. 33. Muscatine L., Porter, J.W., 1977. Reef corals: Mutualistic symbioses adapted to nutrient-poor environments. BioScience 27,454-460.

34. Nahon, S., Nozais, C., Delamare-Deboutteville, J., Escoubeyrou, K., Desmalades, M., Pruski, A.M., Karsten, U., Charles, F., 2012. Trophic relationships and UV-absorbing compounds in a Mediterranean medio-littoral rocky shore community. Journal of Experimental Marine Biology and Ecology 424-425, 59-65. https://doi.org/10.1016/j.jembe.2012.05.009

35. Nishimoto, A., Mito, S., Shirayama, Y., 2009. Organic carbon and nitrogen source of sunken wood communities on continental shelves around Japan inferred from stable isotope ratios. Deep Sea Research Part II: Topical Studies in Oceanography 56, 1683-1688. https://doi.org/10.1016/i.dsr2.2009.05.032

36. O'Connor, R. M., Fung, J. M., Sharp, K. H., Benner, J. S., McClung, C., Cushing, S., Elizabeth R. Lamkin, Alexey I. Fomenkov, Bernard Henrissat, Yuri Y. Londer, Matthew B. Scholz, Janos Posfa, Stephanie Malfatti, Susannah G. Tringe, Tanja Woyke, Rex R. Malmstrom, Devin Coleman-Derr, Marvin A. Altamia, Sandra Dedrick, Stefan T. Kaluziak, Margo G. Haygood, Distel, D. L., 2014. Gill 
bacteria enable a novel digestive strategy in a wood-feeding mollusk. Proceedings of the National Academy of Sciences, 111, E5096-E5104. https://doi.org/10.1073/pnas.1413110111

37. Paalvast, P., van der Velde, G., 2013. What is the main food source of the shipworm (Teredo navalis)? A stable isotope approach. Journal of Sea Research 80, 58-60. https://doi.org/10.1016/j.seares.2013.03.003

38. Parnell, A.C., Inger, R., Bearhop S., Jackson, A.L., 2010. Source partitioning using stable isotopes: coping with too much variation. PLoS ONE 5, $e 9672$. https://doi.org/10.1371/journal.pone.0009672.

39. Pechenik, J. A., Perron, F. E., Turner, R. D., 1979. The role of phytoplankton in the diets of adult and larval shipworms, Lyrodus pedicellatus (Bivalvia: Teredinidae). Estuaries 2, 58-60. https://doi.org/10.2307/1352042

40. Peterson, B.J., Fry, B., 1987. Stable isotopes in ecosystem studies. Annual review of ecology, evolution and systematics 18, $293-320$.

41. Peterson, B.J., Howarth, R.W., Garritt, R.H., 1986. Sulfur and carbon isotopes as tracers of saltmarsh organic matter flow. Ecology 67, 865-874. https://doi.org/10.2307/1939809

42. Popham, J D., Dickson, M.R., 1973. Bacterial associations in the Teredo Bankia australis (Lamellibranchia: Mollusca). Marine Biology 19, 338-340. https://doi.org/10.1007/BF00348904

43. Potts, F. A., 1923. The structure and function of the liver of Teredo, the shipworms. Biological Reviews 1, 1-17. https://doi.org/10.1111/i.1469-185X.1923.tb00527.x

44. R Core Team, 2013. R: A language and environment for statistical computing. R Foundation for Statistical Computing, Vienna, Austria. http://www.R-project.org/.

45. Rau, G.H., Teyssie, J.L., Rassoulzadegan, F., Fowler, S.W., $1990 .{ }^{13} \mathrm{C} /{ }^{12} \mathrm{C}$ and ${ }^{15} \mathrm{~N} /{ }^{14} \mathrm{~N}$ variations among size-fractionated marine particles: implications for their origin and trophic relationships. Marine Ecology-Progress Series 59, 33-38.

46. Sabbadin, F., Pesante, G., Elias, L., Besser, K., Li, Y., Steele-King, C., Stark, M., Rathbone, D.A., Dowle, A.A., Bates, R., Shipway, J.R., Cragg, S.M., Bruce, N.C., McQueen-Mason, S.J., 2018. Uncovering the molecular mechanisms of lignocellulose digestion in shipworms. Biotechnology for Biofuels 11. https://doi.org/10.1186/s13068-018-1058-3

47. Sigman, D.M., Karsh, K.L., Casciotti, K.L., 2009. Nitrogen isotopes in the ocean, in Steele, J.H., Turekian, K.K. Thorpe, S.A. (Eds.), Encyclopedia of Ocean Sciences (update from 2001) Academic Press, London.

48. Turner, Ruth. D. 1966. A survey and illustrated catalogue of the Teredinidae (Mollusca: Bivalvia). Ed. The Museum of Comparative Zoology, Harvard University, Cambridge, Mass.

49. Wada, E. Hattori, A., 1976. Natural abundance of $\%$ in particulate organic matter in the North Pacific Ocean. Geochimica et Cosmochimica Acta 40, 249-251. https://doi.org/10.1016/00167037(76)90183-6

50. Waterbury, J.B., Calloway, C.B., Turner, R.D., 1983. A cellulolytic nitrogen-fixing bacterium cultured from the gland of Deshayes in shipworms (Bivalvia: Teredinidae). Science 221, 1401-1403. https://doi.org/10.1126/science.221.4618.1401

51. Yamanaka, T., Shimamura, S., Chikaraishi, Y., Haga, T., Fujiwara, Y., 2015. Re-evaluation of nutrient sources for deep-sea wood-boring bivalves using the isotopic composition of bulk C, N, S, and amino acid nitrogen. Marine Ecology Progress Series 540, 157-165. https://doi.org/10.3354/meps 11510

52. Zapata-Hernández, G., Sellanes, J., Thiel, M., Henríquez, C., Hernández, S., Fernández, J.C.C., Hajdu, E., 2016. Community structure and trophic ecology of megabenthic fauna from the deep basins in the Interior Sea of Chiloé, Chile (41-43 ${ }^{\circ}$ S). Continental Shelf Research 130, 47-67. https://doi.org/10.1016/j.csr.2016.10.002 
492

493

494

495

496

497

498

499

500

501

502

503

504

505

506

507

508

509

510

511

512

513

514

515

\section{Tables and figures' captions}

Table 1. Stable isotope compositions and $\mathrm{C} / \mathrm{N}$ ratios of potential food sources; $\mathrm{n}$, number of samples. SPOM: Suspended particulate organic matter, SD: Standard deviation.

Table 2. Stable isotope compositions and $\mathrm{C} / \mathrm{N}$ ratios of consumers. Feeding modes are: Xylo, xylotrophy, SF, suspension-feeding; n, number of individuals; SD: Standard deviation.

Fig. 1. Carbon and nitrogen isotope compositions of potential food sources and consumers. The broken line indicates the $\delta^{15} \mathrm{~N}$ average value expected for products resulting from the fixation of atmospheric nitrogen. The ellipse indicates the range of theoretical expected $\delta^{15} \mathrm{~N}$ and $\delta^{13} \mathrm{C}$ values for consumers of alder wood, considering trophic enrichments of $0.30 \%$ and $2.5 \%$ for $\delta^{13} \mathrm{C}$ for $\delta^{15} \mathrm{~N}$, respectively. Dotted lines account for trophic shift of carbon and nitrogen.

Fig. 2. Bayesian mixing model dietary analyses for carbon (A) and nitrogen (B). Boxplots with 50 (in dark gray), 75 (in medium gray) and 95\% (in light gray) credible intervals representing the proportion of Alnus glutinosa: Wood, suspended particulate organic matter: SPOM, and dissolved nitrogen: $\mathrm{N}_{2}$ in the diet of the shipworm Bankia carinata.

Figure S1: Experimental setup. Image of the alder wood packs at the study site within the Bay of Banyuls-sur-Mer, Mediterranean Sea, France. 
516

517

518

519

\begin{tabular}{cccccc}
\hline Sources & $\begin{array}{c}\text { Date or exposure } \\
\text { duration in } \\
\text { months }\end{array}$ & $\mathrm{n}$ & $\delta^{15 \mathrm{~N}(\% \mathrm{o})}$ & $\delta^{13} \mathrm{C}(\% \mathrm{o})$ & $\mathrm{C} / \mathrm{N}$ \\
\hline \multirow{3}{*}{ SPOM } & June 9 & 3 & $2.4 \pm 0.1$ & $-24.5 \pm 0.1$ & $6.5 \pm 0.2$ \\
& July 11 & 4 & $4.8 \pm 0.5$ & $-22.6 \pm 0.1$ & $5.8 \pm 0.6$ \\
& Sept 12 & 3 & $3.9 \pm 0.5$ & $-23.7 \pm 0.1$ & $6.2 \pm 0.8$ \\
& Oct 24 & 4 & $2.6 \pm 0.3$ & $-24.3 \pm 0.7$ & $9.6 \pm 2.7$ \\
& Time integrated & & $3.4 \pm 1.1$ & $-23.8 \pm 0.8$ & $7.0 \pm 1.7$ \\
& 0 & & & & $158 \pm 9$ \\
& 2 & 5 & $-2.8 \pm 0.7$ & $-28.8 \pm 0.5$ & $195 \pm 11$ \\
& 4.5 & 4 & $-2.7 \pm 0.1$ & $-29.8 \pm 0.1$ & $157 \pm 11$ \\
& Time integrated & & $-2.2 \pm 0.5$ & $-29.8 \pm 0.3$ & $-29.3 \pm 0.5$ \\
\hline
\end{tabular}

Table 1. Stable isotope compositions and $\mathrm{C} / \mathrm{N}$ ratios of potential food sources; $\mathrm{n}$, number of samples.

SPOM: Suspended particulate organic matter, SD: Standard deviation.

520

521 
522

523 Table 2. Stable isotope compositions and $\mathrm{C} / \mathrm{N}$ ratios of consumers. Feeding modes are: Xylo, 524 xylotrophy, SF, suspension-feeding; n, number of individuals; SD: Standard deviation.

525

526

\begin{tabular}{|c|c|c|c|c|c|}
\hline $\begin{array}{l}\text { Class } \\
\text { species }\end{array}$ & $\begin{array}{l}\text { Feeding } \\
\text { type }\end{array}$ & $\mathrm{n}$ & $\delta^{15} \mathrm{~N}(\% 0)$ & $\delta^{13} \mathrm{C}(\% 0)$ & $\mathrm{C} / \mathrm{N}$ \\
\hline \multicolumn{6}{|l|}{ Bivalvia } \\
\hline Bankia carinata & Xylo/SF & 25 & $0.5 \pm 0.4$ & $-27.5 \pm 0.6$ & $8.3 \pm 2.5$ \\
\hline Mytilus galloprovincialis & SF & 1 & $4.4 \pm$ n.d. & -20.3 & $3.5 \pm$ n.d. \\
\hline Hiatella arctica & SF & 2 & $4.0 \pm 0.07$ & $-20.1 \pm 0.2$ & $3.8 \pm 0.2$ \\
\hline Musculus subpictus & SF & 1 & $4.1 \pm$ n.d. & -20.8 & $4.0 \pm$ n.d. \\
\hline \multicolumn{6}{|l|}{ Polychaeta } \\
\hline Serpula vermicularis & SF & 4 & $4.9 \pm 0.1$ & $-20.1 \pm 0.3$ & $3.9 \pm 0.1$ \\
\hline Spirobranchus triqueter & SF & 4 & $4.84 \pm 0.2$ & $-19.8 \pm 0.2$ & $3.9 \pm 0.1$ \\
\hline \multicolumn{6}{|l|}{ Ascidiacea } \\
\hline Ascidia conchilega & SF & 1 & $4.6 \pm$ n.d. & $-21.3 \pm$ n.d. & $4.9 \pm$ n.d. \\
\hline
\end{tabular}

527

528

529 


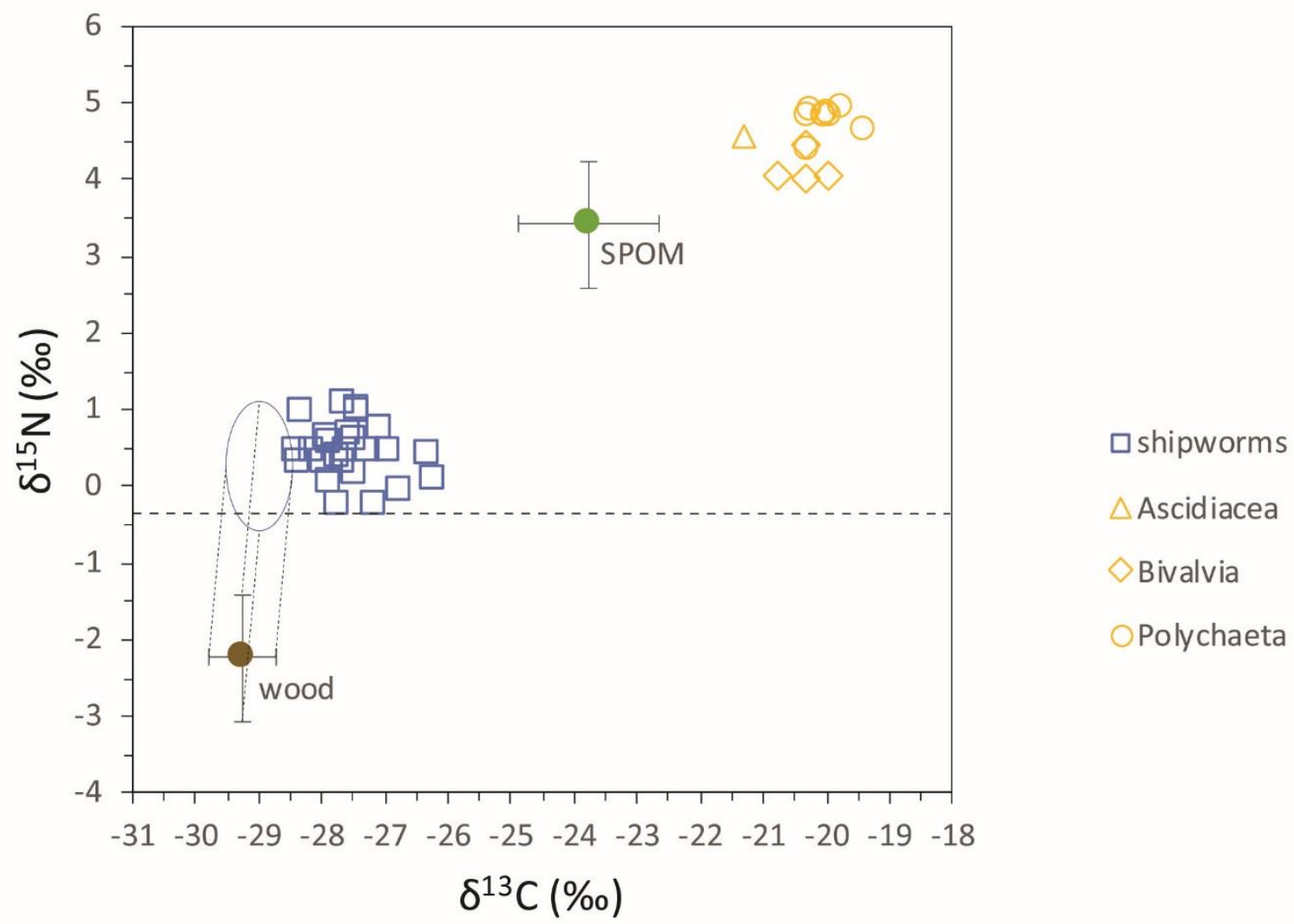

530

531

532

533

534

535

536

537

Fig. 1. Carbon and nitrogen isotope compositions of potential food sources and consumers. The broken line indicates the $\delta^{15} \mathrm{~N}$ average value expected for products resulting from the fixation of atmospheric nitrogen. The ellipse indicates the range of theoretical expected $\delta^{15} \mathrm{~N}$ and $\delta^{13} \mathrm{C}$ values for consumers of alder wood, considering trophic enrichments of $0.30 \%$ and $2.5 \%$ for $\delta^{13} \mathrm{C}$ for $\delta^{15} \mathrm{~N}$, respectively. Dotted lines account for trophic shift of carbon and nitrogen. 

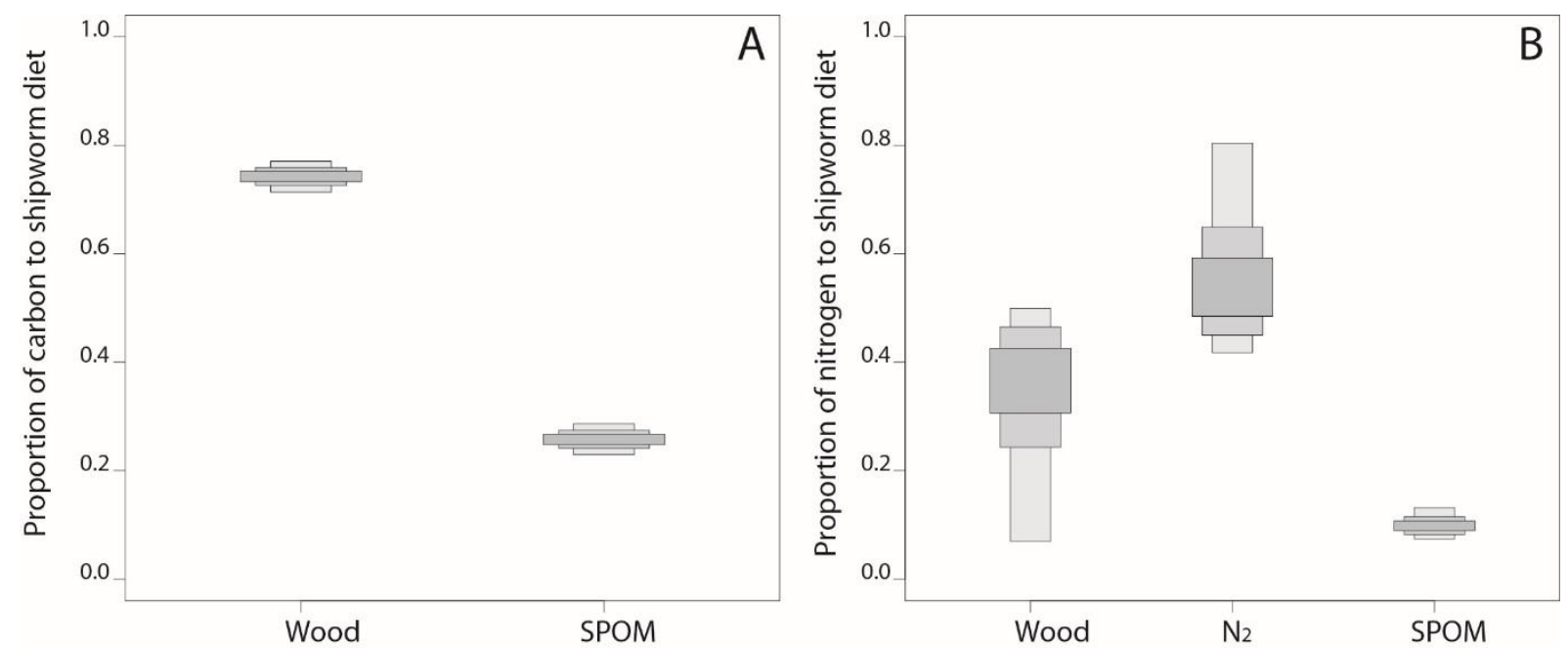

540

541

542

Fig. 2. Bayesian mixing model dietary analyses for carbon (A) and nitrogen (B). Boxplots with 50 (in dark gray), 75 (in medium gray) and 95\% (in light gray) credible intervals representing the proportion of

544 Alnus glutinosa: Wood, suspended particulate organic matter: SPOM, and dissolved nitrogen: $\mathrm{N}_{2}$ in the 545 diet of the shipworm Bankia carinata. 


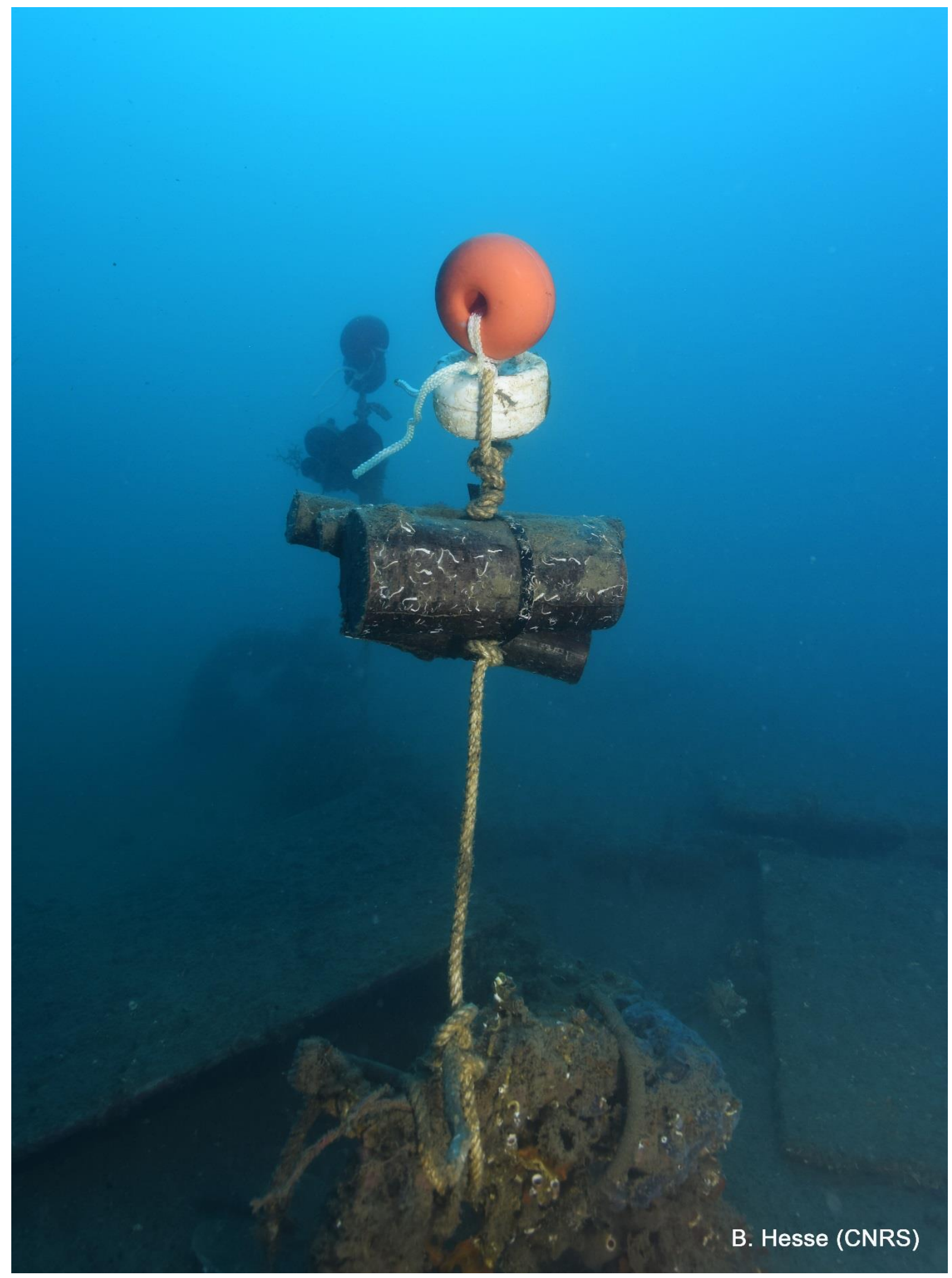

Figure S1: Experimental setup. Image of the alder wood packs at the study site within the Bay of 550 Banyuls-sur-Mer, Mediterranean Sea, France. 